\title{
Mangrove Forest Restoration by Fisheries Communities in Lampung Bay: A study based on perceptions, willingness to pay, and management strategy
}

\author{
Maulana Firdaus ${ }^{1,2, *}$, Katsumori Hatanaka ${ }^{1}$ and Ramadhona Saville ${ }^{1}$ \\ 1 Department of Agribusiness Management, Graduate School of Agriculture, Tokyo University of \\ Agriculture, Tokyo, Japan \\ 2 Research Centre for Marine and Fisheries Socio-Economic, Indonesia Ministry of Marine Affairs and \\ Fisheries, Jakarta, Indonesia. \\ * Correspondence author: 46719401@nodai.ac.jp
}

\begin{abstract}
Mangroves provide benefits and various services to local communities living along coastal areas, particularly fishery communities. Fishery community perceptions are significant in determining attitudes towards improving mangrove conditions, which can also be addressed through restoration activities. This research was conducted to analyze fisheries communities perceptions, willingness to pay (WTP) for mangroves restoration, and mangrove forest management strategies. Field surveys were conducted from July-August 2019 and February-March 2020. Primary data were collected from respondents in four regions (Kalianda Regency, South Lampung Regency, Bandar Lampung City, and Pesawaran Regency) in Lampung Province, Indonesia, which consist of fishers, shrimp farmers, crab and wood seekers, and finfish farmers. The respondents were 193 people, and four experts were involved in the policy scenario analysis. Results revealed a gap in the value of WTP among fishery community groups, in which the average value for fishers is lower than shrimp farmers. The years of formal education significantly influenced the WTP for mangrove restoration. Based on the scenario analysis, scenario 01 become a priority strategy, where four policies (P1 = Mangrove ecotourism development in Lampung Bay; P2 = Mangrove knowledge education and training on processing mangrove based products; $\mathrm{P} 3$ = Restoration and conservation of mangrove forests; and P4 = Community-based management for mangrove forests utilization) show high likelihoods to be simultaneously implemented for mangroves management, with mangrove ecotourism policy as the most decisive policy. For future research, other explanatory variables can be added, such as information on family member characteristics, and to develop a bottom-up policy scenario by identifying and involving the role of the local community.
\end{abstract}

Keywords: fishery communities; logit model; mangrove restoration; perception level; policy scenario

\section{Introduction}

Mangroves provide extensive ecosystem services to fish, shrimp, and society (CarrasquillaHenao et al., 2019). Development in coastal areas have transformed land utilization, and massive conversion of mangroves to settlements and shrimp ponds have occurred. It also damages mangrove ecosystems disrupting their environmental and socio-economic function (Ward et al., 2016). The role of mangrove ecosystems is closely related to the quality of ocean water close to the coast (Kelleway et al., 2017) because the conversion of mangroves will have an impact on the commercial fisheries throughout the surrounding area as well as on its economic value (Tanner et al., 2019). Mangrove ecosystems play an ecologically and economically important role because they have substantial services for humans and the environment (Lee et al., 2014), such as household needs (forest products and various mangrove products), livelihoods, coastal protection, habitat provision, storm protection, and maintenance of water quality (Barbier, 2016; Pearson et al., 2019). 
In the last few decades, mangrove ecosystems have been under constant pressure due to diverse human activities and high population growth rates. Indonesia is known as the country with the largest mangrove forests in the world, with an area of 3,112,989 ha, or $22.6 \%$ of the world's mangrove forest (Giri et al., 2011). On the other hand, Indonesia's mangroves are also experiencing the highest rate of deforestation (Campbell \& Brown, 2015), with total deforestation in the last three decades of $40 \%$, caused by logging, land conversion for agriculture, shrimp ponds and salt land (FAO, 2007). The exploitation of mangroves to meet people's needs tends to be intensive, and it does not conform with conservation rules. The fast expansion of shrimp pond aquaculture has brought up environmental issues about converting ecologically important mangrove areas. The deforestation of mangrove forests and the expansion in aquaculture impact the occurrence of sedimentary organic matter in recent decades (Bao et al., 2013). They could change the quality of ocean waters (Unger et al., 2013). This impact is strongly felt by coastal residents, mainly by fisheries communities who depend their lives on mangroves (Paul \& Vogl, 2011). Some studies suggest that mangrove ecosystems and fisheries have strong connections, particularly in support of economic activities in the fisheries sector (Lau \& Scales, 2016), not only in the capture fisheries but also mariculture in the coastal area (Anneboina \& Kumar, 2017).

In Indonesia, the largest concentration of mangrove forests is in Papua and Sumatera (Hartini et al., 2011). However, Sumatera has experienced a sharp decline in mangroves due to the conversion of shrimp ponds, which is estimated at 60\% (Onrizal, 2010), particularly in Lampung Province, where there were initially 160 thousand ha of mangrove forests, and $85 \%$ (136 thousand ha) of mangroves have been converted into shrimp ponds (Damayanti, 2007), makes the mangrove forest in Lampung Province is the third smallest in Sumatera (Yuliasamaya et al., 2014). Shrimp ponds zone is concentrated in the Lampung Bay area, with a substantial increase of more than 300\%, from 50,615 ha in 2012 to 156,132 ha in 2018 (BPS, 2019). Shrimp pond activities are not the only fisheries activity performed in the coastal area of Lampung Bay. There are at least three other main activities are recorded, such as fishing, crab seekers, and mariculture ${ }^{1}$. These three activities are also highly dependent on mangroves forests. In current conditions, the local government is facing problematic issues related to fishery activities. There are concerns from fishers, crab-seekers, and mariculture farmers about declining income, which is thought to be related to increasing shrimp ponds in Lampung Bay. All have an essential part and involve many parties and groups of people who depend their lives on shrimp ponds, fishing, mariculture, and the existence of mangroves. Mangroves have an indispensable role to play as a counterbalance. Authorities would need a strategy to manage it so that all fisheries and economic activities that rely on ecosystem services can perform sustainably.

Changes in the condition of mangroves in Lampung Bay are not only triggered by the conversion to ponds as mentioned above, but according to Yuliasamaya et al. (2014), some $20 \%$ are a result of abrasion, fishing activities, and land clearing for agriculture. According to de Souza et al. (2015), mangrove degradation is also greatly influenced by community perceptions of the status of the mangroves. In order to overcome mangrove degradation, the strategic plan for the management of mangroves is considered essential. One of the strategies is restoration because it has minimized the impact of mangrove degradation losses and plays an important role in addressing conversion impacts (Romanach et al., 2018). According to Pham et al. (2018), the local community's perceptions significantly influenced the restoration activities. In addition, a pro-environmental attitude also affects restoration activities (Abdullah et al., 2014). According to Dunlap (1994), this attitude is a human response to ecological degradation, measured through the value of willingness to pay (WTP). It is crucial in policy planning and implementation to identify the socio-economic characteristic and perceptional factors that could affect their WTP for the restoration program. This research aims to analyze coastal communities' perceptions, particularly fisheries communities whose lives depend on mangrove ecosystems, fisheries communities' willingness to restore mangrove forests, and the mangrove forest

\footnotetext{
${ }^{1}$ Here, mariculture defined as one of the aquaculture activities defined as an aquatic culture activity conducted at sea, such as grouper, salmon, barramundi and other finfish commodities, seaweed, and bivalve (Neori et al., 2004).
} 
management strategies, particularly in Lampung Bay, Indonesia.

\section{Materials and Methods}

\subsection{Research Area}

The field survey was conducted in July-August 2019 and February-March 2020 in Lampung Bay's coastal area, Lampung Province, Indonesia, which is in four regions which include South Lampung, Kalianda, Bandar Lampung, and Pesawaran (Figure 1). This coastal region is situated at approximately $5^{\circ} 44^{\prime} 47.0^{\prime S} 105^{\circ} 35^{\prime} 16.6^{\prime \prime} \mathrm{E}$ to $105^{\circ} 15^{\prime} 14.6^{\prime \prime E}, 5^{\circ} 33^{\prime} 17.5^{\prime \prime} \mathrm{S}$. Lampung Province has a total area of $35.288,35 \mathrm{Km}^{2}$, including the islands located at the most southeastern part of Sumatera Island. This region has mangrove forests and considerable fisheries potential. The total population is estimated at 7.6 million people, and $60 \%$ live in coastal areas (BPS, 2020).

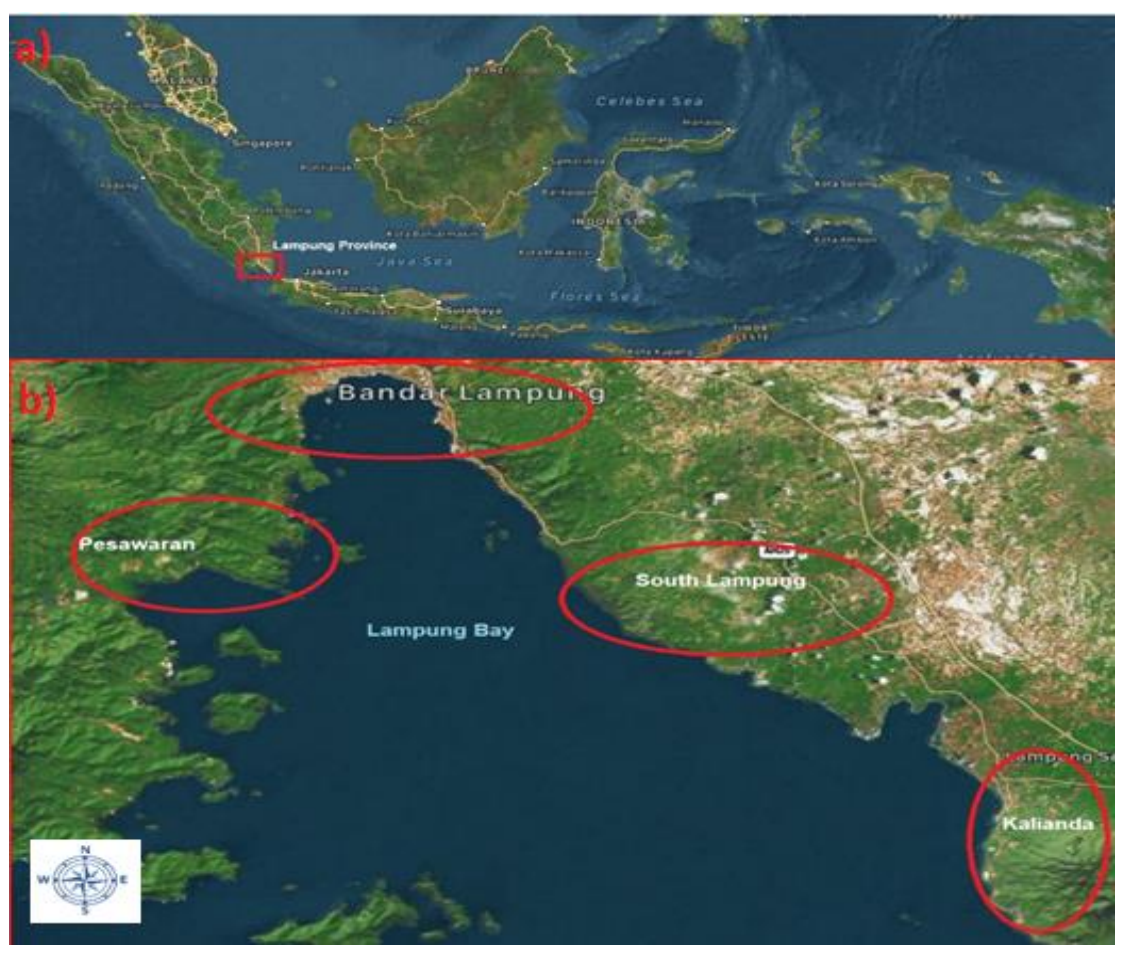

Figure 1. Location Map of (a) Lampung Province, Indonesia; (b) Selected research area (Source: https://satellites.pro/)

\subsection{Research Design}

Respondents were selected purposively through personal interviews conducted at home or the fishing/farming site. Respondents selected with criteria: (1) people who live on the coast and are less than $<3 \mathrm{Km}$ from the mangroves forest boundary; (2) working in the fisheries sector (fishers, shrimp farmers, fish farmers, and crab seekers) and other sectors that carried out around the mangroves forests (e.g., wood seekers). The total sample size is 193 respondents, consists of fishers $(n=41)$, shrimp farmers $(n=107)$, crab and wood seekers $(n=29)$, and finfish farmers $(n=16)$. However, sometimes we experienced difficulties conducting interviews with respondents because of difficulty accessing the respondent's residence. This condition is one of the causes of this research's weakness because it is likely that it is difficult to obtain a proportional number of $\mathrm{n}$ sample respondents to represent the population. However, we try to solve it through a prior agreement with target respondents to meet in a public meeting facility in the village with several potential respondents and interview them personally one by one. Also, focus group discussions (FGD) were performed with four experts, each representing different groups, such as fishermen, shrimp and fish farmers, NGOs, and local government, to develop a scenario strategy for mangrove management. The composition of respondents and experts in each analysis in this research is different and will explain each data analysis sub-chapter in detail. 


\subsection{Data Analysis}

\subsubsection{Profitability analysis of commercial fisheries associated with mangroves}

Profitability analysis were conducted to asses the profit of commercial fisheries associated with mangroves by calculating and comparing the benefits and costs ( $\mathrm{Nas}, 2016)$. The profit implies the benefit they get concerning the presence of mangrove forests (Giri et al., 2011). It is given as follows:

$$
\text { Profit }=T R-(T F C+T V C)
$$

where $T R$ is the total revenue; $T F C$ is the total fixed cost; and TVC is the total variable cost. In this research, the commercial fisheries activities consist of fishing, shrimp farming, crab and wood seeking, and finfish farming. These activities done by the local community in or near the mangrove forest. The total sample size to conduct this analysis is 193 respondents, consist of fishers ( $n=41)$, shrimp farmers $(n=107)$, crab and wood seekers $(n=29)$, and finfish farmers $(n=$ 16).

\subsubsection{Analysis of fisheries community perceptions of mangrove forests}

The fisheries community's perception has been analyzed using scoring techniques. The score is determined using the "Likert Scale." The measurement is by confronting a respondent with a question and asked to provide answers "strongly agree," "agree," "less agree," "disagree" and "strongly disagree." These answers are given a suspension of 5, 4, 3, 2, 1 in sequence. There are seven questions regarding perception, including (1) knowledge of the condition and quality of mangroves; (2) knowledge of mangroves services; (3) Benefits received from mangroves; (4) Awareness of the regulations related to mangroves utilization; (5) recent mangroves conversion; (6) Initiative to protect the existing mangroves; and (7) Initiative to restore and conserve mangroves. The data collected from the questionnaire then calculated the total score for each question by adding up each respondent's ratings. The selection of the level of perception is grouped into five groups (Table 1). The perception level can be known as the formulation of perception through three mechanisms (collection, interpretation, and organization). The arithmetic mean of all questionnaire responses was used to simplify calculations and figure out all respondent's trends to answer questions. The formula calculates the average value of the responses of all respondents (Fink, 2003):

$$
\underline{x}=\frac{\sum X_{i}}{n} \#
$$

where $\underline{x}$ is the mean of each response; $\sum \quad X_{i}$ is the response score for each respondent $i$; and $n$ is the number of respondents who gave responses. Not all respondents gave complete responses to this perception question. From a total of 193 respondents as described above, this analysis only involved 101 respondents ( $\mathrm{N}$ fishers $=41 ; \mathrm{N}$ shrimp farmers $=60$ ). The rest of the respondents are not involved to avoid bias. The scores of the responses obtained are then converted into a scale. To connect the respondents' responses to the level of perception, the average value obtained from the survey of respondent's answers reflects a representation of their level of perception. With five answer choices, the interval is equal to 5 , the highest value for each answer is 5 , while the lowest value for the answer is 1 , then the answer interval is equal to 0.8 (Table 1). The scale is determined in advance by finding the interval value referring to the Sturges rule (Fink, 2003) with the following calculation:

$$
\text { Interval }=\frac{\text { Highest weight }- \text { Lowest weight }}{\text { number of criteria }}=\frac{5-1}{5}=0.8 \#
$$


Interval values have been calculated, then scaled to determine the level of perception so that the respondents know each component of the assessment. The scale of the level of perception can be seen in Table 1.

Table 1. Levels of perception of the fisheries community on mangrove forests and their benefits

\begin{tabular}{cc}
\hline Interval of perception value & Perception level \\
\hline $4.20-5.00$ & Very high \\
$3.40-4.20$ & High \\
$2.60-3.40$ & Medium \\
$1.80-2.60$ & Low \\
$1.00-1.80$ & Very low \\
\hline
\end{tabular}

Source: adapted from Leary (2004).

\subsubsection{Willingness to pay (WTP) analysis}

The dataset was designed to provide information on the respondents' WTP for mangrove forests' environmental services. The WTP is by using the open-ended method of questioning. This approach is achieved by asking the respondent personally they will donate or no, and also how much if they will donate for the restoration program, so we can know the average value of each group. In this research, data from stated preference surveys were used to estimated the coefficients of logit models. The respondents were asked if they were willing to pay a certain amount of money for the restoration program by a certain amount. Let 1 indicate that they are willing to pay for the restoration program and 0 that they are not. Data were also collected on the socio-economic characteristics of the respondents. The logit models shown as follows (Bhandari \& Heshmati, 2010):

$$
Y_{i}=\ln \ln \left(\frac{P R_{i}}{1-P R_{i}}\right)=\alpha+\beta_{i} X_{i} \#
$$

where $Y$ is the log of the odds ratio called the logit or log-odds which is a linear function of the explanatory variables. $P R_{i}$ is the probability of WTP of $\mathrm{i}$ individuals, $P R_{i}$ ranges between 0 and 1 ; the vector $X_{i}$ contains attributes of respondents' characteristics; $\beta$ is the corresponding unknown regression coefficients to be estimated. The cumulative logistic distribution function in (3) can be represented as:

$$
P R_{i}=E\left(X_{i}\right)=\frac{1}{1+e^{-\left(\alpha+\beta_{i} X_{i}\right)}} \#
$$

If $P R_{i}$ is the probability of WTP for restoration program, then $\left(1-P R_{i}\right)$ is the probability of not willing to pay:

$$
1-P R_{i}=\frac{1}{1+e^{\left(\beta_{i}+\beta_{i} X_{i}\right)}} \#
$$

The odds ratio is defined as:

$$
\frac{P R_{i}}{1-P R_{i}}=\frac{1+e^{\left(\beta_{i}+\beta_{i} X_{i}\right)}}{1+e^{-\left(\beta_{i}+\beta_{i} X_{i}\right)}}=e^{\left(\beta_{i}+\beta_{i} X_{i}\right)} \#
$$

The odds ratio is the ratio of beneficial to unbeneficial cases of WTP in the current condition. This preference depends on the values of the explanatory variables. Taking the natural log of equation 6 , we get equation 3 . This model is estimated using the log likelihood estimation method. From the coefficients of logistic regression, it is possible to measure the individual's estimated probability of paying for the restoration program. This helps to classify according to their WTP and their individual characteristics (Bhandari \& Heshmati, 2010). 


\subsubsection{Scenario analysis for mangrove management strategies}

The mangrove management strategy in Lampung Bay was adopted from a strategic plan determined by the local government (Lampung provincial forestry service) as an institution with authority to manage mangrove forests in the Province of Lampung. There are at least four central policies for mangrove management obtained from the strategic plan document, namely: 1) Mangrove ecotourism development in Lampung Bay (P1); (2) Mangrove knowledge education and training on processing mangrove-based products (P2); (3) Restoration and conservation of mangrove forests (P3); and (4) Community-based management for mangrove forests utilization (P4). This research determined the best mangrove management strategy to use the scenario analysis approach "SMIC-prob" developed by Godet (2006). This analysis is based on the theory of opportunities, specifically subjective probability, to assess the likelihood of an event occurring or not. In the SMIC-Prob, the score of possible scenario combinations is calculated, where the number of scenarios or events observed is $r=2^{n}$, where $n$ is the number of scenarios observed (Fauzi, 2019). In our case $2^{4}$, in other words, 16 alternatives scenarios were analyzed. The highest probability score (\%) scenario will be used as the recommended scenario in the research. The scenarios are not future reality but can predict future conditions, with all possible current and future terms (Bruun et al., 2002). The steps to carry out this analysis begin with determining the number of events to be analyzed. In this research, there were four events or policies that might be applied. Next, determine the simple probability and conditional probability for each scenario, as follows:

$$
\begin{aligned}
& P(i / j)=\text { The probability of } i \text { scenario if } j \text { scenario occur } \\
& P(i / j)=\text { The probability of } i \text { scenario if } j \text { scenario not occur }
\end{aligned}
$$

The requirements for each of the opportunities above in order to operate are:

$$
0 \leq P(i) \leq 1
$$

where,

$$
\begin{gathered}
P(i / j) P(j)=P(j / i) P(i)=P(i j) \\
P(i / j) P(j)+P(i / \underline{j}) P(\underline{j})=P(i)
\end{gathered}
$$

To determine the probability combination score using the quadratic programmimg method through the objective function (Fauzi, 2019):

$\min \sum_{i j}^{n}\left[P(i \mid j) P(i)-\sum_{k=1}^{r} t(i j k) \pi_{k}\right]^{2}+\sum_{i j}^{n}\left[P(i \underline{j}) P(\underline{j})-\sum_{k=1}^{r} s(i j k) \pi_{k}\right]^{2} \#(9)$

with constraints,

$$
\sum_{k=1}^{r} \pi_{k}=1, \text { and } \pi_{k} \geq 0 \text { for all } k
$$

where $\pi_{k}$ is the probability of the scenario where the value of the minimization solution is sought in the equation (8). The value of $t(i j k)$ equal to 1 when event $i$ and $j$ occur in $k$ scenario, and 0 (zero) when events $i$ and $j$ do not occur in $k$ scenario. The value of $s(i j k)$ equal to 1 when the value of events $i$ occur in $k$ scenario but event $j$ doest not occur. Conversely, $s(i j k)$ equal to 0 (zero) if event $i$ does not occur, but event $j$ occurs in $k$ scenario.

A questionnaire with a Likert scale was used to obtain information related to the probability for expert opinion in this research, which was then converted into probabilities through 
standardization techniques. The number of experts consisted of four people representing four different groups, including (1) the coordinator of the traditional fishing community in the coast of Lampung Bay; (2) the coordinator of the shrimp farmers association; (3) the director of regional development planning (government side), and (4) representatives from the Lampung Mangrove Center (LMC) - NGOs. Experts are asked to present their opinions regarding the probabilities for implementing the mangrove management strategy policy with a range of answers from impossible (1) to very possible (5). The expert then answers by giving a circle to one of these scores. To determine the conditional probabilities, the expert will then compare this scenario's probability with the scenario if this policy cannot be implemented on the same Likert scale. The standardization techniques as follows (Medina, 2015):

$$
P\left(F_{i}\right)=\frac{v_{i}-\min }{\max -\min }
$$

where, $v_{i}$ is the score given by expert $i$, while the max and min values represent the maximum and minimum values of the Likert scale, respectively, in this analysis, it is necessary to ensure that the answers given by each expert are consistent. To do so, the SMIC method is used in this analysis because it has the advantage of providing a free software program (the SMIC-ProbExpert ${ }^{2}$ ), which is user-friendly, the procedure is very simple and the results obtained are usually easily interpreted (Godet, 2006; Medina et al., 2015). The determination of input matrices for the SMIC-Prob-Expert analysis was a very difficult task. That is why a three-hour discussion was organized, with the various probabilities estimated by consensus. The software input has two parts of a matrice. The first matrix includes an expert assessment of the pairwise probability of co-occurrence of the processes. The second matrix includes the estimated probabilities for the existence of pairwise processes if the other process in the pair does not occur.

Furthermore, sensitivity analysis is conducted, which enables separate powerful or dominant policies from policies that are subordinate to them. The sensitivity analysis presented in the form of an elasticity coefficient refers to an equation from Duperrin \& Godet (1975), and the SMIC-Prob-Expert software completed it. In this case, sensitivity analysis is used to define the important policy and provides information on which policy needs to be improved or prevented to achieve the expected condition.

\section{Results and Discussion}

\subsection{Characteristic of respondents}

Data presented in Table 2 shows the results of selected socio-economic characteristics of the respondents. There are four groups: fishermen, shrimp farmers, crab and wood seekers, and finfish farmers. The average age of crab and wood seekers was older than the other groups, with an average of 41.24 years and the largest age group for all respondents between 26 and 35 . This age group includes the age range still productive in the working place. The average number of years of formal education for finfish farmers is the highest compared to other respondent groups dominated by respondents with 7-9 years of formal education, which translates to junior high school level and 13-15 years, translating to a bachelor's degree and the lowest was fishers with average years of formal education of 8.41 years, with a standard deviation of 3.26. Education was related to knowledge; the higher the amount of education, the determine the intensity of knowledge on the environment (Forlina \& Chambers, 2011). However, the relationship between education and awareness has almost reached significance to environmental concerns (Kopnina, 2012). Furthermore, low education people are identical with low skills (Van Der Ploeg \& Poelhekke, 2017).

The total number of family sizes for all respondents ranges between 1-8 individuals. Respondents with a family size of 1 person are those who are not married and live separately (not dependent on their parents). However, the fisher's family size is the largest, with an average

\footnotetext{
${ }^{2}$ The SMIC-Prob-Expert program can be accessed at http://en.laprospective.fr/methods-ofprospective/softwares/62-smic-prob-expert.htm
} 
of 4.56 people. The family size will affect expenditure and poverty. The large family size of the population could encourage growth in housing, negatively impacting the environment if related to its environmental effects (Bradbury et al., 2014). The income measured is the total income generated from fisheries. The average income of finfish farmers is the highest compared to other groups of respondents, with an average income of IDR 42,518,000/year (1 USD = IDR 14,000). Compared to the Regional Minimum Wage (RMW) value in Lampung Province in 2020, which is IDR $29,160,000 /$ year, the average income of respondents in the fishers group and crab-wood seekers group has a lower income than RMW. The income of this group is very dependent on the condition of the resources in the environment. If the income is below the RMW, the income is insufficient to meet basic needs (Sen \& Ariizumi, 2013).

\subsection{Overview of Commercial Fisheries Associated with Mangroves in Target Areas}

Mangroves have various ecological functions and very important for the surrounding community (Tanner et al., 2019). This research will show four types of commercial fisheries that are allegedly associated with mangroves. The commercial fisheries are limited to fishing, crab seeker, shrimp farming, and finfish mariculture in Lampung Bay. Finfish mariculture is included in the analysis because various studies say that mangroves function as a deterrent or filter waste from coastal areas that will enter the waters. Though several factors may impact the performance of the mariculture, because it is located in waters near the coast, it is assumed to have a connection with the presence of mangroves, according to previous studies (Ahmed \& Glaser, 2016).

Shrimp farming activities carried out by the most community in the target area using traditional and semi-intensive systems. Vannamei shrimp is the most cultivated commodity. The number of harvests in a year ranges from 1-2 times per year. Traditional shrimp farmer has 1-2 pond units per person, with an average pond size of $0.5-1$ ha/pond. In this research, fishing activities are focused on fishers who have a high dependence on mangrove forests or who have fishing ground around the mangrove areas. These fishers are small scale fishers. The fishing gear used is multi gears, such as beach nets, handline, and traps. These fisher's target includes mullet fish, mangrove jackfish, and various shrimp types whose habitat is in mangroves. This fisher is fishing with the number of fishing trips reaching $5-6$ trips/week. Shrimp farmers and fishers generally make this activity their primary source of income. Various things work by crab and wood-seekers, this group usually has another primary livelihood, such as work in shrimp farms, and only some consider crab and wood-seekers as their livelihoods.

Catching crabs is commonly done by digging into holes and traps stored in the mangrove forest and taken a few days later. Crab seekers usually collect wood or twigs from fallen or dead mangrove trees as firewood for household needs, and some of it is sold after being processed into charcoal. They do activities catching crabs and looking for wood 3-4 times a week. Moreover, mariculture activities in Lampung Bay were carried out in waters near the coast or less than one mile from the shoreline. Grouper, Asian sea bass, silver pomfret, and golden trevally is the type of fish grown commercially. The period of grows out between 6 - 9 months or harvest once a year. The mariculture system carried out using floating net cages.

Based on the analysis (Table 3), the commercial fisheries with the most significant profit are shrimp farming, which reaches IDR $41,552,000 /$ year. In traditional shrimp farming, these activities rely more on natural feed. Feeding during grows out ranges from 2-4 times. The highest variable cost of shrimp farming is for fingerlings. Fixed costs include electricity and land rent or tax. Fishing activities have the lowest profit compared with other activities. Fishing activities have the most significant variable cost value; this is due to the fuel cost component. Fuel is the most significant and contributes more than $50 \%$ of the total variable cost. Crab and wood seeker activities have the smallest revenue value, but the profit is higher than fishing and mariculture. It is because the crab and wood seeker activities do not incur any costs. This activity is traditionally carried out without using special tools or only with bare hands. 
Table 2. Frequency Distribution of Respondents by Selected Socio-Economic Characteristics

\begin{tabular}{|c|c|c|c|c|c|c|c|c|c|c|c|c|c|c|}
\hline \multirow{2}{*}{ Selected Characteristics } & \multicolumn{3}{|c|}{ Fishers } & \multicolumn{3}{|c|}{ Shrimp Farmers } & \multicolumn{3}{|c|}{ Crab and Wood Seekers } & \multicolumn{3}{|c|}{ Finfish Farmers } & \multicolumn{2}{|c|}{ Total } \\
\hline & Freq & $\%$ & Central tendency & Freq & $\%$ & Central tendency & Freq & $\%$ & Central tendency & Freq & $\%$ & Central tendency & Freq & $\%$ \\
\hline \multicolumn{15}{|l|}{ Age (in years) } \\
\hline$<25$ & 2 & 5 & $\bar{x}=39.85$ & 29 & 27 & $\bar{x}=35.96$ & 3 & 10 & $\bar{x}=41.24$ & 5 & 31 & $\bar{x}=29.19$ & 39 & 20 \\
\hline $26-35$ & 15 & 37 & $\sigma=9.92$ & 36 & 34 & $\sigma=14.16$ & 9 & 31 & $\sigma=12.59$ & 7 & 44 & $\sigma=8.00$ & 67 & 35 \\
\hline $36-45$ & 13 & 32 & & 17 & 16 & & 7 & 24 & & 4 & 25 & & 41 & 21 \\
\hline $46-55$ & 8 & 20 & & 14 & 13 & & 5 & 17 & & 0 & 0 & & 27 & 14 \\
\hline $56+$ & 3 & 7 & & 11 & 10 & & 5 & 17 & & 0 & 0 & & 19 & 10 \\
\hline Total & 41 & 100 & & 107 & 100 & & 29 & 100 & & 16 & 100 & & 193 & 100 \\
\hline \multicolumn{15}{|l|}{ Years of formal education } \\
\hline$<7$ & 3 & 7 & $\bar{x}=8.41$ & 52 & 49 & $\bar{x}=11.07$ & 2 & 7 & $\bar{x}=9.76$ & 1 & 6 & $\bar{x}=11.63$ & 58 & 30 \\
\hline $7-9$ & 23 & 56 & $\sigma=3.26$ & 14 & 13 & $\sigma=4.76$ & 10 & 34 & $\sigma=3.60$ & 2 & 13 & $\sigma=2.42$ & 49 & 25 \\
\hline $10-12$ & 7 & 17 & & 8 & 7 & & 5 & 17 & & 11 & 69 & & 31 & 16 \\
\hline $13-15$ & 8 & 20 & & 27 & 25 & & 12 & 41 & & 0 & 0 & & 47 & 24 \\
\hline $16+$ & 0 & 0 & & 6 & 6 & & 0 & 0 & & 2 & 13 & & 8 & 4 \\
\hline Total & 41 & 100 & & 107 & 100 & & 29 & 100 & & 16 & 100 & & 193 & 100 \\
\hline \multicolumn{15}{|l|}{ Family size (person) } \\
\hline$<=2$ & 2 & 5 & $\bar{x}=4.56$ & 14 & 13 & $\bar{x}=4.26$ & 12 & 41 & $\bar{x}=3.59$ & 6 & 38 & $\bar{x}=2.69$ & 34 & 18 \\
\hline $3-4$ & 19 & 46 & $\sigma=1.32$ & 50 & 47 & $\sigma=1.57$ & 7 & 24 & $\sigma=2.32$ & 10 & 63 & $\sigma=1.40$ & 86 & 45 \\
\hline $5-6$ & 17 & 41 & & 34 & 32 & & 6 & 21 & & 0 & 0 & & 57 & 30 \\
\hline $7+$ & 3 & 7 & & 9 & 8 & & 4 & 14 & & 0 & 0 & & 16 & 8 \\
\hline Total & 41 & 100 & & 107 & 100 & & 29 & 100 & & 16 & 100 & & 193 & 100 \\
\hline \multicolumn{15}{|c|}{ Household Income from mangrove utilization (IDR .000/Year) } \\
\hline$<12,000$ & 5 & 12 & $\bar{x}=40,866$ & 28 & 26 & $\bar{x}=30,786$ & 3 & 10 & $\bar{x}=26,726$ & 0 & 0 & $\bar{x}=42,518$ & 36 & 19 \\
\hline $12,000-24,000$ & 18 & 44 & $\sigma=27,342$ & 40 & 37 & $\sigma=27,342$ & 9 & 31 & $\sigma=11,508$ & 9 & 56 & $\sigma=37,884$ & 76 & 39 \\
\hline $24,001-35,980$ & 13 & 32 & & 16 & 15 & & 11 & 38 & & 3 & 19 & & 43 & 22 \\
\hline $35,981-48,000$ & 1 & 2 & & 6 & 6 & & 5 & 17 & & 0 & 0 & & 12 & 6 \\
\hline $48,001-60,000$ & 2 & 5 & & 8 & 7 & & 1 & 3 & & 0 & 0 & & 11 & 6 \\
\hline$>60,000$ & 2 & 5 & & 9 & 8 & & 0 & 0 & & 4 & 25 & & 15 & 8 \\
\hline Total & 41 & 100 & & 107 & 100 & & 29 & 100 & & 16 & 100 & & 193 & 100 \\
\hline
\end{tabular}


Table 3. Profitability analysis of Fisheries Activities in Target Area, 2020.

\begin{tabular}{lccccc}
\hline \multirow{2}{*}{ Fisheries activities } & \multicolumn{5}{c}{ Financial Analysis (IDR/Years) } \\
\cline { 2 - 6 } & Revenue & $\begin{array}{c}\text { Variable } \\
\text { Cost }\end{array}$ & Fixed Cost & Total Cost & Profit \\
\hline Shrimp Farming & $54,222,000$ & $10,346,000$ & $2,324,000$ & $12,670,000$ & $41,552,000$ \\
& $(3,873)$ & $(739)$ & $(166)$ & $(905)$ & $(2,968)$ \\
Fishing & $48,258,000$ & $17,206,000$ & $17,206,000$ & $24,318,000$ & $23,940,000$ \\
& $(3,447)$ & $(1,229)$ & $(508)$ & $(1,737)$ & $(1,710)$ \\
Crab and Wood & $26,754,000$ & & & 98,000 & $26,656,000$ \\
Seeker & $(1,911)$ & & - & $(7)$ & $(1,904)$ \\
a. Wood & $8,148,000$ & - & & - & $8,148,000$ \\
& $(582)$ & & 98,000 & 98,000 & $18,508,000$ \\
b. Crab & $18,606,000$ & - & $(7)$ & $(7)$ & $(1,322)$ \\
& $(1,329)$ & & & 290,000 \\
Finfish Mariculture & $212,842,00$ & $238,070,000$ & $52,920,000$ & 290,000 & $-78,148,000$ \\
& 0 & $(17,005)$ & $(3,780)$ & $(20,785)$ & $(-5,582)$ \\
& $(15,203)$ & & & & \\
\hline
\end{tabular}

Note: Numbers in brackets show value in USD currency; 1 USD = 14,000 IDR

Based on the results, mariculture in Lampung Bay is not competitive. Even though the number of revenues is the highest, it has harmful or excessive profits. The value of the variable cost is higher than the revenue (Table 3). The essential spending on mariculture is for the feed (trash fish). The trash fish feed price continued to increase dramatically from 2018-2020, reaching 200-300 per cent or the original price of IDR $9,800 / \mathrm{kg}$ to IDR $30,000 / \mathrm{kg}$. According to the respondents, what triggers the decline of mariculture is the high mortality rate of fish. Viruses and bacteria are the leading causes of fish mortality in mariculture (Rimmer \& Glamuzina, 2019). Particularly in Lampung Bay, according to farmers, fish mortality is also caused by the red tide (harmful algal blooms) that often occurs in Lampung Bay, which is consistent with many research findings in Lampung Bay. Since 2012, the red tide in Lampung Bay has caused fish mortality and economic losses, and the red tide is due to inadequate water quality conditions, one of which is caused by pollution from the mainland (Puspasari et al., 2018). Good mangrove forests can reduce this impact because mangroves have an ecosystem function as water quality improvement (Brander et al., 2012).

\subsection{Mangrove Forest Perceptions and Willingness to Pay (WTP) for Mangrove Restoration}

\subsubsection{Mangrove forest perceptions}

The fisheries community's perceptions are divided into two, i.e., fishers' perceptions (include crab seekers) and shrimp farmers. Fisheries communities who give their perceptions in this research are precisely the people who live around the mangrove forest. In this research, mariculture farmers perceptions were not analyzed because the number of respondents was insufficient ( $<10$ farmers) and reduced the bias from the analysis because their place of residence is far from the mangrove area. Fisher's groups' perception level is the highest. The fishers group perception level's average value is 3.25, and shrimp farmers are 3.19 (Table 4). This situation shows which perception best represents the knowledge or perception factors that are important to them. A higher perception value for fishers shows that fishers better understand and perceive mangroves' benefit on their livelihoods. This finding are in line with the study by Stone et al. (2008) and Susilo et al. (2017), the fisher communities perceive the most benefit from mangroves. Fishers in their daily life fishing in mangrove forests were not far from where their lives. Thus, they will feel the benefits and impacts of changes in mangroves' condition and quality on their livelihoods. Their high dependence on mangroves is a factor in their level of perception higher than shrimp farmers. Mangrove ecosystems are significant for sustainably and refuge fishing for 
high economic value species and the importance of sustainable fishing. Mangrove forests are closely related to fishing because mangrove forests provide marine habitats for fishes, crabs, and shrimp (Santos et al., 2017). According to Abdullah et al. (2016), population dependence on mangroves is very high; around $30 \%$ of households engage in commercial fishing in or near the mangrove. Although the fisher's perception of mangrove knowledge and condition in the area is lower (1.95) compared to shrimp farmers (2.08), fishers have more willingness to do mangrove restoration than shrimp farmers (Table 4). Due to several factors, such as Das's (2017) results, mangroves restoration has significantly increased the catch of mangrove-dependent fish in both sectors, contributing almost one-fourth of the natural strands contribution.

All fishers and shrimp farmers have a strong understanding of mangrove forests benefits in their daily lives. It implicitly means a connection between fishers, shrimp farmers, or people living in the mangrove forest because mangrove products are significant income sources for coastal communities, especially in tropical countries (Datta et al., 2012). The fisheries community recognizes that there has been a massive transformation of mangrove forests into shrimp ponds, tourist sites, and settlements. It can be seen from field observations where most mangrove areas are affected by human activity. They cut mangroves for use as coal, house construction, and household appliances. Some of the mangroves were felled to build community houses on the beach and land borders. In this situation, they understand that it is essential to set down regulations on managing mangrove areas and enforce strict sanctions on those who commit violations. The fisheries community has little knowledge of the rules and regulations for managing mangrove areas. Through this research, the community agrees that the government should make a specific rule on managing mangrove areas. They must agree to comply with the regulations developed to protect the mangrove area, and if they break those rules, they will be charged.

Table 4. Perceptions of Fisheries Communities Towards Mangroves Forest

\begin{tabular}{lcccc}
\hline \multirow{2}{*}{ Perceptions of mangrove forest } & \multicolumn{2}{c}{ Fishers } & \multicolumn{2}{c}{ Shrimp Farmer } \\
\cline { 2 - 5 } & PV & PL & PV & PL \\
\hline 1. Knowledge of the condition and quality of mangroves & 3.88 & High & 3.58 & High \\
2. Knowledge of ecosystem services from the mangroves & 2.80 & Medium & 3.08 & Medium \\
3. Perceptions of the benefits of mangroves in daily life & 3.78 & High & 3.50 & High \\
4. Awareness of the regulations related mangroves utilization & 1.95 & Low & 2.08 & Low \\
5. Perceptions of recent mangrove forest conversion activities & 3.63 & High & 3.50 & High \\
6. Initiative to protect the existing mangroves & 3.22 & Medium & 3.27 & Medium \\
7. Initiative to restore and conserve mangroves & 3.51 & High & 3.35 & Medium \\
\hline \multicolumn{1}{c}{ Average } & 3.25 & \multicolumn{3}{c}{3.19} \\
\hline
\end{tabular}

Note: $\mathrm{PV}=$ Perception Value; $\mathrm{PL}=$ Perception Level

\subsubsection{WTP for mangrove restoration}

Based on the perceptions of the fisheries community, efforts are required to restore and maintain mangrove forests. The community must take this effort voluntarily. To determine the community's willingness to restore mangroves, this is addressed by quantifying their WTP in cash. The value of WTP for the restoration or conservation of ecosystems by local people can be measured by assessing their knowledge of the benefits provided and produced by mangroves (Datta et al., 2012). The stated preference approach was adopted for the WTP assessment. The respondents indicated the amount they are willing to pay for ecosystem services. The stated value was analyzed and summarized in Table 5 . In this approach, respondents were asked if they were willing to perform and participate in mangroves restoration activites. Respondents who stated that they are not willing were given a value of 0 , while respondents willing to undertake the restoration of mangroves were offered various payment rates, ranging from IDR 10,000/year to IDR 2,000,000/year.

There is a gap value of WTP between the fisher and shrimp farmer groups. For fisher's WTP ranges from IDR 20,000/year to IDR 500,000/year, and for shrimp farmers, it ranges from IDR 10,000/year to 
IDR 1,000,000/year. WTP's median for both is the same: IDR 50,000/year. WTP's highest frequency for fishers and shrimp farmers is between 0 - IDR 50,000 per year, with the frequency of both being more than $50 \%$. Nevertheless, the average WTP for shrimp farmers was higher than fishers; the average WTP for shrimp farmers was almost twice the WTP value for fishers (Table 5). The average WTP for fishers and shrimp farmers is IDR 169,470/year/person. This value can be interpreted as the value given by each fishery community around the mangrove forest used for restoration. Mangroves restoration cost per hectare is 52,006 USD/ha or IDR 728,084,000/ha (Bayraktarov et al., 2016). Then, if the mangrove restoration costs per hectare proposed by Bayraktarov et al. (2016) divided by the average value of individual WTP in this research (IDR 728,084.00/ha/year: IDR 169,470 ha/year/person), it is expected that there must be 4,296 people who are willing to donate the cash to restore one hectare of mangroves forest in a year. For necessity, this is quite a lot, since in general, there are only around 500 to 1500 people in a coastal village near mangrove forests (BPS, 2019). If a village's population is estimated to be 1,500 , then the ideal minimum WTP for mangrove restoration is IDR 485,400/capita/year (34 USD/year).

The data were subjected to logit model analysis to analyze the influence of respondents' socioeconomic characteristics on the WTP of fishers and shrimp farmers. Considering the fact that the factors influencing the choice behaviors may be different between fishers and shrimp farmers. The initial variables and the result of the logit model analysis summarized in Table 6. Using the Jamovi software, the coefficients were estimated. Five explanatory variables were included in the model, including variables about income, years of formal education, age, family size, and occupation. Years of formal education significantly at 0.05 level of confidence and has a positive effect on WTP. The explanatory variables such as income, age, family size, and type of occupation did not appear to impact WTP, since the P-value was not significant at 0.05 or a 0.10 level of confidence. Years of formal education are the variable that most influences the WTP ( 0.05 level of confidence). These results indicate that each individual's formal education background is the most influential factor on the WTP preferred behavior, and not the different types of work that exist within the fisheries communities (fishers and shrimp farmers). These findings are consistent with Lalika et al. (2017), education level background has a significant effect on the attitudes of WTP because education can increase the awareness and attitudes of individuals to contribute to conservation initiatives. The individuals with higher education preferred to pay more for mangrove restoration activities (Pham et al., 2018).

Table 5. Distribution of Respondents According the WTP for Mangrove Conservations

\begin{tabular}{|c|c|c|c|c|}
\hline \multirow{2}{*}{ Value (IDR/Year) } & \multicolumn{2}{|c|}{ Fishers } & \multicolumn{2}{|c|}{ Shrimp Farmer } \\
\hline & Frequency & $\%$ & Frequency & $\%$ \\
\hline $0-50,000(0-3.57)$ & 22 & 54 & 31 & 52 \\
\hline $50,001-100,000(3.58-7.14)$ & 8 & 20 & 10 & 17 \\
\hline $100,001-150,000(7.15-10.71)$ & 1 & 2 & 1 & 1 \\
\hline$>500,000(>10.71)$ & 10 & 24 & 18 & 30 \\
\hline Total & 41 & 100 & 60 & 100 \\
\hline WTP Value & (IDR/year & & \multicolumn{2}{|c|}{ (IDR/Year) } \\
\hline Min & $20,000(1.43$ & & \multicolumn{2}{|c|}{$10,000(0.71)$} \\
\hline Max & $500,000(35$ & & \multicolumn{2}{|c|}{$1,000,000(71.38)$} \\
\hline Mean & $118,440(8.4$ & & \multicolumn{2}{|c|}{$220,500(15.75)$} \\
\hline Median & $50,000(3.5)$ & & \multicolumn{2}{|c|}{$50,000(3.57)$} \\
\hline
\end{tabular}

Note: Numbers in brackets show value in USD currency; 1 USD = 14,000 IDR 
Table 6. Result of logit model of WTP responses for mangrove restoration

\begin{tabular}{lrrrrr}
\hline \multirow{2}{*}{ Variables } & \multicolumn{5}{c}{ Binary logit model } \\
\cline { 2 - 6 } & \multicolumn{1}{c}{ Coef. } & Std. Err. & Z & P-value & Odds ratio \\
\hline Income & -0.157 & 0.384 & -0.409 & 0.683 & 0.855 \\
Years of formal education & 1.053 & 0.389 & 2.708 & $0.007^{* *}$ & 2.865 \\
Age & -0.931 & 0.837 & -1.112 & 0.266 & 0.394 \\
Family size & -0.648 & 0.804 & -0.806 & 0.42 & 0.523 \\
Occupation & 0.171 & 0.573 & 0.299 & 0.765 & 0.1187 \\
Intercept & 4.409 & 4.072 & 1.083 & 0.279 & 82.216 \\
-2 log likelihood & 107.855 & & & & \\
Percentage of correct & 80 & & & & \\
Number of observations & 101 & & & \\
\hline Note: ** show significance level of 5\%. Estimates represent the log odds of “ $\mathrm{Y}=1$ 1" vs. “ $\mathrm{Y}=0$ ” &
\end{tabular}

According to Amiri et al. (2015), the probability of rejecting the bids by a large family size was higher than the family with a smaller size because more family members were less capable financially. They thus had a relatively lower WTP for conservation. Income is not significantly suggested because it only calculates income from fishery activities related to mangroves in this research. They likely have other sources of income beyond fisheries activities. In general, the per capita income earned is very low, with an average of IDR $8,805,600$ / year or IDR 733,825 / month. This income is classified as low income because it is below the minimum regional wage value (IDR 2,445.141 / month). However, the variables considered could only explain $80 \%$ of the variations notable in WTP. Other variables not included in this analysis may be responsible for the WTP preference behavior.

\subsection{Alternative scenarios of mangrove management strategy}

The mangrove forests in Lampung Bay have been degraded. The conversion of land into settlements and shrimp ponds is one of the primary factors. The alternative scenarios refer to the coastal management strategic plan document of Lampung Province, established by the Lampung regional development planning agency (Bappeda). These scenarios contain four top-down policies formulated by the regional government for mangrove management in Lampung Bay, were: (P1) Mangrove ecotourism development in Lampung Bay; (P2) Mangrove knowledge education and training on processing mangrove-based products; (P3) Restoration and conservation of mangrove forests; and (P4) Community-based management for mangrove forests utilization. The experts were asked to discuss single and combined conditional probabilities of the four policies. Processing experts' subjective probabilities using the SMIC-Prob-Experts software revealed 16 scenarios for this case (Table 7). Inside these scenarios, a group of scenarios with a higher probability of occurrence exists that we called "priority strategy."

The highest probability of the SMIC-Prob-Expert result is a potential scenario (priority strategies) so that it is limited without having to disclose the entire scenario (Vivanco et al., 2011). In this research, selecting five scenarios with the highest probability value in line with Godet (2006), which states that it is essential to select several baselines "priority strategy" scenarios with the highest probability value:

1. Scenario 01 (1111) had a 0.224 probability of occurrence. This scenario showed that the four policies defined can be implemented. This scenario becomes a top priority "ideal scenario" to be implemented.

2. Scenario $16(0000)$ is the opposite situation with scenario 01 . Scenario 16 indicates none of the policies can be implemented. In other words, all policies are not appropriate, so that the policymaker must choose another policy that is more suitable to be implemented. 
3. Scenario 02 (1110) had a 0.130 probability occurrence. This scenario indicated that three policies defined can be implemented, and the P4 policy cannot be implemented. It means that the policy regarding community-based management for mangrove forests utilization is not an option or is eliminated when the policy options are faced with limitations.

4. Scenario 03 (1101) had a 0.079 probability. The same situation with scenario 02 and the P3 policy cannot be implemented. It means that policy regarding restoration and conservation of mangrove forests are not an option for managing mangrove forests. Restoration effort requires a significant budget, and it will be challenging to do if the government has a limited budget. In this scenario, the policy choices prefer to prioritize the policies related economic aspects and community capacity building.

5. Scenario 05 (1011) had a 0.057 probability. The same situation with the 02 and 03 scenarios. P2 policy cannot be implemented. It means that policy regarding mangrove knowledge education and training on processing mangrove-based products are not an option in this scenario. Increasing local communities' capacity to use mangroves in a product is considered ineffective in mangrove forest management. Excessive and uncontrolled use of mangroves due to competition between local communities can lead to the depletion of mangrove forests (Dahdouh-Guebas et al., 2000; Ghosh et al., 2015).

Table 7. Hierarchy of alternative scenarios for management mangrove according to their probability of occurrence

\begin{tabular}{lcc}
\hline No & Scenarios & Probability \\
\hline $01^{*}$ & 1111 & 0.224 \\
$02^{*}$ & 1110 & 0.130 \\
$03^{*}$ & 1101 & 0.079 \\
04 & 1100 & 0.046 \\
$05^{*}$ & 1011 & 0.057 \\
06 & 1010 & 0.054 \\
07 & 1001 & 0.022 \\
08 & 1000 & 0.052 \\
09 & 0111 & 0.030 \\
10 & 0110 & 0.023 \\
11 & 0101 & 0.044 \\
12 & 0100 & 0.011 \\
13 & 0011 & 0.000 \\
14 & 0010 & 0.007 \\
15 & 0001 & 0.020 \\
$16^{*}$ & 0000 & 0.200 \\
\hline
\end{tabular}

Note: * five main priority alternative scenarios based on their probability value; the second column identifies for each scen ario the occurrence (1) and non-occurrence (0) of each outlined policies. For example, in the case of scenario 02-1110 indicates that this is scenario no 2 and P1, P2, P3 occurrence (1) and P4 non-occurrence (0). In other words, this scenario suggest that the first three policies will be implemented, and P4 cannot be implemented.

The five priority strategies had a $0.69(69 \%)$ probability, representing more than half of the total scenarios revealed. $\mathrm{P} 1$ policies are present in almost all scenarios (except scenario 16). Policies related to mangrove ecotourism development are a priority choice that policymakers can implement in managing mangrove forests in Lampung Bay. Mangrove ecotourism is safe for the mangrove ecosystem and significant for economic development and mangrove conservation (Azis et al., 2018). This ecotourism development begins with minor improvements made to an existing product. Therefore, it is the service provider's responsibility to be creative and innovative when developing an ecotourism 
product that will satisfy and attract visitors (Mattila, 2011). In this case, the service provider can consist of the government as the sole manager or the government in partnership with the local community and NGOs or, in other words, according to Abdullah et al. (2014), is called adaptive co-management between local communities, government institutions, and NGOs. Scenario 16 is the second priority scenario, but all policies are 0 or cannot be implemented. Relying upon these findings, there are many factors why the planned policies cannot be implemented, among others, due to the community's conflicts at the local level and the unpreparedness of the implementing agencies (Mclaughlin, 1987). An extensive network of policymakers (government side) in each community is necessary, and spatial planning as part of policy planning must also be fulfilled (Pacini et al., 2014). Thus, if these requirements cannot be met, all policies cannot be implemented. The experts concluded that they should build another scenario beyond this option. For example, Thompson et al. (2018) and Ruzol et al. (2020) note the new option scenario can be built using participatory approaches involving public, private, and civil sector stakeholders relating to mangrove forests. This approach is called participatory forestry, or peopleoriented forestry, which aims to transfer authority and forest management responsibilities from the local or national government to local level institutions (e.g., village's government and local community organizations) can promote local participation and collaboration in mangrove forest restoration (Tacconi, 2007; Jashimudin \& Inoue, 2012; Vaidya \& Mayer, 2014).

Based on the logistic regression analysis results in the previous sub-section, years of formal education were significant predictors of the WTP fisheries communities for mangrove restoration. Besides, according to Botelho (2012), education is the strongest influencing factor in the degree of compliance to regulations and is an important factor in promoting the mangrove management policy scenario. Improvement of mangrove quality will positively impact fisheries activities because most fishers believed that mangroves' marine nursery benefits were important to their communities. The fishers group had a higher level of perception on mangroves than the shrimp farmers group but had lower average years of formal education. Educational programs provided by the government or other institutions to the fishers' community are necessary to increase their participation more because they can become extension networks or agents in government policy programs for mangrove management.

The success of the mangroves management scenario is determined by the participation of local communities or stakeholders (Wever et al., 2012; Jumnongsong et al., 2015). The attitude "perceptions" of willingness to support mangrove restoration can be used as a reference to measure how probably the local community will participate in supporting the policies that will be established to manage mangroves. The participation forestry approach can be supported and prepared to conduct education and awareness of the local community about the importance of mangrove forests' function. Years of formal education represent the level of individual education, and it can be assumed that individuals who have a higher level of education will be more knowledgeable and aware of the importance of mangroves and willing to restore them. According to Stone et al. (2008), education may also increase interest in enforcing mangrove reforested areas. The significant impact of the education factor on WTP mangrove restoration was mentioned in the previous study. The local people recognised the benefit and importance of mangrove for the future (Abdullah et al., 2014). This research's results are complementary and emphasize the importance of paying attention to the education of local communities by the government so that any government policy programs can be realized.

\subsubsection{Sensitivity analysis}

Sensitivity analysis conducts to investigate which policies have the most influence and which policies are highly dependent. This sensitivity analysis is essential and valuable for policymakers to anticipate possible consequences of scenario probability change. Sensitivity analysis in Table 8 presents the elasticity coefficient where the horizontal raw indicates the influence level of a policy to other policies while the vertical column indicates the level of dependency of a policy relative to other policies. 
Table 8. Sensitivity analysis of Mangroves management strategy policies

\begin{tabular}{lcccc|c}
\hline \multicolumn{1}{c}{ P1 } & P2 & P3 & P4 & Influence \\
\hline 1- P1 & 1,000 & 0.049 & 0.231 & 0.06 & 0.340 \\
2- P2 & -0.041 & 1,000 & 0.075 & 0.107 & 0.223 \\
3- P3 & -0.008 & -0.006 & 1,000 & -0.028 & 0.041 \\
4- P4 & -0.099 & -0.028 & -0.061 & 1,000 & 0.188 \\
Dependence & 0.148 & 0.083 & 0.366 & 0.194 & 0,000 \\
\hline Note: & & & \\
P1 = Mangrove ecotourism development in Lampung Bay & & & \\
P2 = Mangrove knowledge education and training on processing mangrove-based products & & \\
P3 = Restoration and conservation of mangrove forests & & \\
P4 = Community-based management for mangrove forests utilization & & \\
0.340 = The policy with the highest level of influence \\
0.366 = The policy with the highest level of dependency
\end{tabular}

Based on Table 8, the policy combined with a negative elasticity coefficient value means that each policy alternative has a contradictory or non-complementary relationship. For example, for the alternative policy matrix P3-P4, the value is -0.028 , meaning that if the probability of P3 increases by $10 \%$, then the probability $\mathrm{P} 4$ will decrease by $2.8 \%$. In other words, the policy of restoration and conservation of mangrove forests will reduce the probability of implementing a community-based management policy for mangrove forest utilization. Table 8 shows the most decisive or most influential policy with the highest elasticity coefficient value $(0.340)$ is $\mathrm{P} 1$. It means that changes to the P1 policy will have a significant impact on other policies. Meanwhile, the policy with the highest dependency is P3 with elasticity coefficient values of 0.366 , followed by P4 with a value of 0.194 . It means the P3 and P4 are the most sensitive policies to changes on other policies probability. Therefore, for this case, the P1 policy is recommended as the most critical policy for implementation.

\section{Conclusions}

This research has complemented the literature on mangrove management based on the perception and WTP of mangrove restoration. Based on their perception level, fisheries communities recognize the importance of mangroves supporting their livelihoods. Mangrove forests must be appropriately managed to ensure their sustainability. Mangroves damaged by human activity must be restored. The WTP for fisheries communities to carry out restoration is shown by the value of money they can donate to the forest restoration program. The WTP value for restoring mangroves between fishers and shrimp farmers is different, where the average WTP value for fishers is IDR 118,440 per year (8.46 USD/year), and for shrimp farmers, IDR 220,500 per year (15.75 USD/year). The most donation option is S IDR 50,000 per year (3.57 USD/year). This WTP value can be considered inadequate, which is not sufficient to cover the expenses of restoring mangrove forests in the target area. Regarding the determinant of fisheries communities WTP, the higher years of formal education is significantly influenced the WTP for restoration mangroves in Lampung Bay. Individuals with a higher educational background have a higher probability of WTP because they might be aware of the restoration program's benefits. This result implies the importance of prioritizing the educational aspect of local communities living around mangroves to create mutually beneficial relationships between humans and mangroves.

From a policy perspective, this empirical research porivdes important input to the regulatory process and helps frame the scenario policy to seek out effective strategies that can be implemented. Based on the scenario analysis, the four policies ( $P 1=$ Mangrove ecotourism development in Lampung Bay; $\mathrm{P} 2=$ Mangrove knowledge education and training on processing mangrove based products; $\mathrm{P} 3=$ Restoration and conservation of mangrove forests; and P4=Community-based management for mangrove forests utilization), has a great opportunity to be simultaneously implemented and become a "priority strategy" for mangroves management in Lampung Bay. However, this must be supported by 
spatial planning, technical planning, and an extensive network in each community in policy implementation to achieve a high level of participation from the public, private, and civil stakeholders. Sensitivity analysis shows that the most critical policy to implement is the mangrove ecotourism policy (P1). Findings taken from this research are expected to be an academic knowledge source for understanding the fisheries communities' perceptions, which depend on mangroves. The perceptions of the fisheries community, mangroves degradation impacting their livelihood income. The willingness to restore has become an entry point for policymakers to involve this community in making effective programs. In general, this research also contributes to the literature to lay the groundwork for mangrove management to implement effective programs and create sustainable ecosystems that can be implemented in other areas with the same issues. Lastly, it is worth mentioning some limitations of the research on its application side. Some of the important explanatory variables may have been left out from the analysis. The current data does not contain information, such as some information on family members' characteristics (e.g., family members' income, occupation). The income information on this research is only limited to fishery activities, and the respondents may have income from other activities. Also, determining the policy scenario is worth mentioning in this research. It is only based on policies listed in the strategic plan document, which are top-down, does not consider proposals, or identifies from the community side (bottom-up), which could be included in future research.

Author Contributions: M. Firdaus performed the literature review, experimental design, analyzed and interpreted the data, prepared the manuscript text, and manuscript edition. R. Saville performed data interpretation and manuscript preparation as well as edition. K. Hatanaka provided insight regarding data interpretation and supervised the whole process of this research

Conflicts of Interest: The authors declare no potential conflict of interest regarding the publication of this work. In addition, the ethical issues including plagiarism, informed consent, misconduct, data fabrication and, or falsification, double publication and, or submission, and redundancy have been entirely witnessed by the authors

Acknowledgements: This work was supported by Science and Technology Research Partnership for Sustainable Development (SATREPS), Ministry of Marine and Fisheries Affairs Indonesia, Japan Science and Technology Agency (JST), and Japan International Cooperation Agency (JICA) program for research projects targeting global issues and involving partnerships between researchers in Japan and developing countries. We express our gratitude here. We also wish to thank BBPBL team, Lampung grouper communication forum (Forkel) and Head of the fisheries and marine affairs office of Lampung province for their cooperation in this research

\section{References}

Abdullah, A. N. M., Stacey, N., Garnett, S. T., \& Myers, B. (2016). Economic dependence on mangrove forest resources for livelihoods in the Sundarbans, Bangladesh. Forest Policy and Economics, 64, 15-24. https://doi.org/10.1016/j.forpol.2015.12.009

Abdullah, K., Said, A. M., \& Omar, D. (2014). Community-based conservation in managing mangrove rehabilitation in Perak and Selangor. Procedia-Social and Behavioral Sciences, 153, 121-131

Ahmed, N., \& Glaser, M. (2016). Coastal aquaculture, mangrove deforestation and blue carbon emissions: Is REDD+ a solution? Marine Policy, 66, 58-66. https://doi.org/10.1016/j.marpol.2016.01.011

Amiri, N., Emadian, S.F., Fallah, A. et al. (2015). Estimation of conservation value of myrtle (Myrtus communis) using a contingent valuation method: A case study in a Dooreh forest area, Lorestan Province, Iran. For. Ecosyst. 2, 30. https://doi.org/10.1186/s40663-015-0051-6

Anneboina, L. R., \& Kavi Kumar, K. S. (2017). Economic analysis of mangrove and marine fishery linkages in India. Ecosystem Services, 24, 114-123. https://doi.org/10.1016/j.ecoser. 2017.02.004

Azis, S. S. A., Sipan, I., \& Sapri, M. (2018). Creating an innocuous mangrove ecosystem: Understanding the influence of ecotourism products from Malaysian and international perspectives. Ocean \& Coastal Management, 165, 416-427. 
Badan Pusat Statistik Indonesia (BPS). Lampung Province in Figures 2019. BPS-Statistics Indonesia. Lampung: Badan Pusat Statistik

Badan Pusat Statistik Indonesia (BPS). Lampung Province in Figures 2020. BPS-Statistics Indonesia. Lampung: Badan Pusat Statistik

Bao, H., Wu, Y., Unger, D., Du, J., Herbeck, L. S., \& Zhang, J. (2013). Impact of the conversion of mangroves into aquaculture ponds on the sedimentary organic matter composition in a tidal flat estuary (Hainan Island, China). Continental Shelf Research, 57, 82-91. https://doi.org/10.1016/j.csr.2012.06.016

Barbier, E. B. (2016). The protective service of mangrove ecosystems: A review of valuation methods. Marine Pollution Bulletin, 109(2), 676-681. https://doi.org/10.1016/j.marpolbul.2016.01.033

Bayraktarov, E., Saunders, M. I., Abdullah, S., Mills, M., Beher, J., Possingham, H. P., Mumby, P. J., \& Lovelock, C. E. (2015). The cost and feasibility of marine coastal restoration. Ecological Applications, 26(4), 1055-1074. https://doi.org/10.1890/15-1077.1

Bhandari, A. K., \& Heshmati, A. (2010). Willingness To Pay For Biodiversity. October 2013, 37-41. https://doi.org/10.1080/10548408.2010.507156

Botelho, A. (2012). The impact of education and training on compliance behavior and waste generation in European private healthcare facilities. Journal of Environmental Management, 98, 5-10. https://doi.org/10.1016/j.jenvman.2011.12.003

Bradbury, M., Peterson, M. N., \& Liu, J. (2014). Long-term dynamics of household size and their environmental implications. Population and Environment, 36(1), 73-84. https://doi.org/10.1007/s11111-014-0203-6

Brander, L. M., J. Wagtendonk, A., S. Hussain, S., McVittie, A., Verburg, P. H., de Groot, R. S., \& van der Ploeg, S. (2012). Ecosystem service values for mangroves in Southeast Asia: A meta-analysis and value transfer application. Ecosystem Services, 1(1), 62-69. https://doi.org/10.1016/j.ecoser.2012.06.003

Bruun, H., Hukkinen, J., \& Eklund, E. (2002). Scenarios for coping with contingency: the case of aquaculture in the Finnish Archipelago Sea. Technological Forecasting and Social Change, 69(2), 107-127.

Campbell, A., \& Brown, B. (2015) Indonesia's vast mangroves are a treasure worth saving. The conversation. Retrieved from http://theconversation.com/indonesias-vast-mangroves-are-atreasure-worth-saving-39367/. Accessed 18 November 2020)

Carrasquilla-Henao, M., Ban, N., Rueda, M., \& Juanes, F. (2019). The mangrove-fishery relationship: A local ecological knowledge perspective. Marine Policy, 108(August). https://doi.org/10.1016/j.marpol.2019.103656

Dahdouh-Guebas, F., Mathenge, C., Kairo, J. G., \& Koedam, N. (2000). Utilization of mangrove wood products around Mida Creek (Kenya) amongst subsistence and commercial users. Economic Botany, 54(4), 513-527. https://doi.org/10.1007/BF02866549

Damayanti, N (2007, September 5). Hutan Bakau di Pantai Timur Lampung Tersisa 10\%. Tempo news. retrieved from https://koran.tempo.co/read/nusa/110247/hutan-bakau-di-pantai-timurlampung-tersisa-10-persen

Das, S. (2017). Ecological Restoration and Livelihood: Contribution of Planted Mangroves as Nursery and Habitat for Artisanal and Commercial Fishery. World Development, 94, 492-502. https://doi.org/10.1016/j.worlddev.2017.02.010

Datta, D., Chattopadhyay, R. N., \& Guha, P. (2012). Community based mangrove management: A review on status and sustainability. Journal of Environmental Management, 107, 84-95. https://doi.org/10.1016/j.jenvman.2012.04.013

de Souza Queiroz, L., Rossi, S., Calvet-Mir, L., Ruiz-Mallén, I., García-Betorz, S., Salvà-Prat, J., \& de Andrade Meireles, A. J. (2017). Neglected ecosystem services: Highlighting the socio-cultural perception of mangroves in decision-making processes. Ecosystem Services, 26, 137-145. 
https://doi.org/10.1016/j.ecoser.2017.06.013

Dunlap, R. E. (1994). International attitudes towards environment and development. Green globe yearbook of international co-operation on environment and development, 1994, 115-126.

Duperrin, J. C., \& Godet, M. (1975). SMIC 74-a method for constructing and ranking scenarios. Futures, 7(4), 302-312. https://doi.org/10.1016/0016-3287(75)90048-8

FAO., (2007). The world's mangroves 1980-2005. Rome: Food and Agriculture Organization of the United Nations. Retrieved from http://www.fao.org/3/a1427e/a1427e00.htm

Fauzi, A. (2019). Teknik analisis keberlanjutan. Gramedia Pustaka Utama.

Fink, A. (2003). How to manage, analyze, and interpret survey data (No. 9). London: Sage Publications, Inc.

Forlina, C., \& Chambersb, D. (2011). Teacher preparation for inclusive education: Increasing knowledge but raising concerns. Asia-Pacific Journal of Teacher Education, 39(1), 17-32. https://doi.org/10.1080/1359866X.2010.540850

Ghosh, A., Schmidt, S., Fickert, T., \& Nüsser, M. (2015). The Indian Sundarban mangrove forests: history, utilization, conservation strategies and local perception. Diversity, 7(2), 149-169. https://doi.org/10.3390/d7020149

Giri, C., Ochieng, E., Tieszen, L. L., Zhu, Z., Singh, A., Loveland, T., Masek, J., \& Duke, N. (2011). Status and distribution of mangrove forests of the world using earth observation satellite data. Global Ecology and Biogeography, 20(1), 154-159. https://doi.org/10.1111/j.1466-8238.2010.00584.x

Godet, M. (2006). Creating Futures: Scenario Planning as a strategic management tool (pp. 280). Washington, DC: Economica. Economica Brookings diffusion.

Hartini, S., Saputro, G. B., Yulianto, M., \& Suprajaka. (2010). Assessing the used of remotely sensed data for mapping mangroves Indonesia. International Conference on Electric Power Systems, High Voltages, Electric Machines, International Conference on Remote Sensing - Proceedings, 210-215.

Jashimuddin, M., \& Inoue, M. (2012). Community forestry for sustainable forest management: Experiences from Bangladesh and policy recommendations. Formath, 11, 133-166. https://doi.org/10.15684/formath.11.133

Jumnongsong, S., Gallardo, W. G., Ikejima, K., \& Cochard, R. (2015). Factors Affecting Fishers' Perceptions of Benefits, Threats, and State, and Participation in Mangrove Management in Pak Phanang Bay, Thailand. Journal of Coastal Research, 299, 95-106. https://doi.org/10.2112/jcoastres-d-12-00257.1

Kelleway, J. J., Cavanaugh, K., Rogers, K., Feller, I. C., Ens, E., Doughty, C., \& Saintilan, N. (2017). Review of the ecosystem service implications of mangrove encroachment into salt marshes. Global Change Biology, 23(10), 3967-3983. https://doi.org/10.1111/gcb.13727

Kopnina, H. (2012). Education for sustainable development (ESD): The turn away from "environment" in environmental education? Environmental Education Research, 18(5), 699-717. https://doi.org/10.1080/13504622.2012.658028

Lalika, M. C. S., Meire, P., Ngaga, Y. M., \& Sanga, G. J. (2017). Willingness to pay for watershed conservation: are we applying the right paradigm? Ecohydrology and Hydrobiology, 17(1), 33-45. https://doi.org/10.1016/j.ecohyd.2016.12.004

Lau, J. D., \& Scales, I. R. (2016). Identity, subjectivity and natural resource use: How ethnicity, gender and class intersect to influence mangrove oyster harvesting in The Gambia. Geoforum, 69, 136146. https://doi.org/10.1016/j.geoforum.2016.01.002

Leary, M. R. (2004). Introduction to behavioral research methods. New Zealan: L Pearson Education

Lee, S. Y., Primavera, J. H., Dahdouh-Guebas, F., Mckee, K., Bosire, J. O., Cannicci, S., Diele, K., Fromard, F., Koedam, N., Marchand, C., Mendelssohn, I., Mukherjee, N., \& Record, S. (2014). Ecological role and services of tropical mangrove ecosystems: A reassessment. Global Ecology and Biogeography, 23(7), 726-743. https://doi.org/10.1111/geb.12155

Mattila, N. (2011). Co-creating a Tourism Product: Case of St. Lapland. Rovaniemi University of Applied 
Sciences, pp. 1-77.

McLaughlin, M. W. (1987). Learning from experience: Lessons from policy implementation. Educational evaluation and policy analysis, 9(2), 171-178. https://doi.org/10.3102/01623737009002171

Medina, E., de Arce, R., \& Mahía, R. (2015). Barriers to the investment in the Concentrated Solar Power sector in Morocco: A foresight approach using the Cross Impact Analysis for a large number of events. Futures, 71, 36-56.

Ministry of Marine and Fisheries Affairs. (2016). Marine and Fisheries Affairs in Figures 2016. MMAF. ID. Jakarta: Kementerian Kelautan dan Perikanan

Nas T. F. (2016). Cost-benefit analysis: Theory and application. Lexington Books.

Neori, A., Chopin, T., Troell, M., Buschmann, A. H., Kraemer, G. P., Halling, C., Shpigel, M., \& Yarish, C. (2004). Integrated aquaculture: Rationale, evolution and state of the art emphasizing seaweed biofiltration in modern mariculture. Aquaculture, 231(1-4), 361-391. https://doi.org/10.1016/j.aquaculture.2003.11.015

Onrizal, O. (2017). Perubahan tutupan hutan mangrove di pantai timur sumatera utara periode 19772006. Jurnal Biologi Indonesia, 6(2).

Pacini, C., Wossink, A., Giesen, G., \& Huirne, R. (2004). Ecological-economic modelling to support multiobjective policy making: a farming systems approach implemented for Tuscany. Agriculture, Ecosystems \& Environment, 102(3), 349-364. https://doi.org/10.1016/j.agee.2003.08.010

Paul, B. G., \& Vogl, C. R. (2011). Impacts of shrimp farming in Bangladesh: Challenges and alternatives. Ocean and Coastal Management, 201-211. https://doi.org/10.1016/j.ocecoaman.2010.12.001

Pearson, J., McNamara, K. E., \& Nunn, P. D. (2019). Gender-specific perspectives of mangrove ecosystem services: Case study from Bua Province, Fiji Islands. Ecosystem Services, 38(June), 100970. https://doi.org/10.1016/j.ecoser.2019.100970

Pham, T. D., Kaida, N., Yoshino, K., Nguyen, X. H., Nguyen, H. T., \& Bui, D. T. (2018). Willingness to pay for mangrove restoration in the context of climate change in the Cat Ba biosphere reserve, Vietnam. Ocean \& Coastal Management, 163, 269-277. https://doi.org/10.1016/j.ocecoaman.2018.07.005

Puspasari, R., Sugianti, Y., Rustam, A., Adi, R. A., Sagala, S. S., \& Pranowo, W. S. (2018). The outbreak of Chochlodinium sp.: The red tide maker in the coastal of Lampung Bay. IOP Conference Series: Earth and Environmental Science, 176(1). https://doi.org/10.1088/1755-1315/176/1/012021

Rimmer, M. A., \& Glamuzina, B. (2019). A review of grouper (Family Serranidae: Subfamily Epinephelinae) aquaculture from a sustainability science perspective. Reviews in Aquaculture, 11(1), 58-87. https://doi.org/10.1111/raq.12226

Romanach, S. S., DeAngelis, D. L., Koh, H. L., Li, Y., Teh, S. Y., Barizan, R. S. R., \& Zhai, L. (2018). Conservation and restoration of mangroves: Global status, perspectives, and prognosis. Ocean \& Coastal Management, 154, 72-82.

Ruzol, C. D., Camacho, A. C. D., Sabino, L. L., Garcia, J. E., Gevaña, D. T., \& Camacho, L. D. (2020). A materialist-idealist divide? Policy and practice in participatory mangrove rehabilitation in the Philippines. Environmental Science \& Policy, 112, 394-404. https://doi.org/10.1016/j.envsci.2020.06.026

Santos, L. C. M., Gasalla, M. A., Dahdouh-Guebas, F., \& Bitencourt, M. D. (2017). Socio-ecological assessment for environmental planning in coastal fishery areas: A case study in Brazilian mangroves. Ocean and Coastal Management, 138, 60-69. https://doi.org/10.1016/j.ocecoaman.2017.01.009

Sen, A., \& Ariizumi, H. (2013). Teen families, welfare transfers, and the minimum wage: Evidence from Canada. Canadian Journal of Economics, 46(1), 338-360. https://doi.org/10.1111/caje.12004

Stone, K., Bhat, M., Bhatta, R., \& Mathews, A. (2008). Factors influencing community participation in mangroves restoration: A contingent valuation analysis. Ocean \& Coastal Management, 51(6), 
476-484. https://doi.org/10.1016/j.ocecoaman.2008.02.001

Susilo, H., Takahashi, Y., \& Yabe, M. (2017). Evidence for mangrove restoration in the Mahakam Delta, Indonesia, based on households' willingness to pay. Journal of Agricultural Science, 9(3), 30-41. https://doi.org/10.5539/jas.v9n3p30

Tacconi, L. (2007). Decentralization, forests and livelihoods: theory and narrative. Global environmental change, 17(3-4), 338-348. https://doi.org/10.1016/j.gloenvcha.2007.01.002

Tanner, M. K., Moity, N., Costa, M. T., Marin Jarrin, J. R., Aburto-Oropeza, O., \& Salinas-de-León, P. (2019). Mangroves in the Galapagos: Ecosystem services and their valuation. Ecological Economics, 160(June 2018), 12-24. https://doi.org/10.1016/j.ecolecon.2019.01.024

Thompson, B. S. (2018). The political ecology of mangrove forest restoration in Thailand: Institutional arrangements and power dynamics. Land Use Policy, 78, 503-514. https://doi.org/10.1016/j.landusepol.2018.07.016

Unger, D., Herbeck, L. S., Li, M., Bao, H., Wu, Y., Zhang, J., \& Jennerjahn, T. (2013). Sources, transformation and fate of particulate amino acids and hexosamines under varying hydrological regimes in the tropical wenchang/wenjiao rivers and estuary, Hainan, china. Continental Shelf Research, 57, 44-58. https://doi.org/10.1016/j.csr.2012.02.014

Vaidya, A., \& Mayer, A. L. (2014). Use of the participatory approach to develop sustainability assessments for natural resource management. International Journal of Sustainable Development \& World Ecology, 21(4), 369-379. https://doi.org/10.1080/13504509.2013.868376

Van Der Ploeg, F., \& Poelhekke, S. (2017). The Impact of Natural Resources: Survey of Recent Quantitative Evidence. Journal of Development Studies, 53(2), 205-216. https://doi.org/10.1080/00220388.2016.1160069

Vivanco-Aranda, M., Mojica, F. J., \& Martínez-Cordero, F. J. (2011). Foresight analysis of tilapia supply chains (Sistema Producto) in four states in Mexico: Scenarios and strategies for 2018. Technological Forecasting and Social Change, 78(3), 481-497.

Ward, R. D., Friess, D. A., Day, R. H., \& Mackenzie, R. A. (2016). Impacts of climate change on mangrove ecosystems: a region by region overview. Ecosystem Health and Sustainability, 2(4). https://doi.org/10.1002/ehs2.1211

Wever, L., Glaser, M., Gorris, P., \& Ferrol-Schulte, D. (2012). Decentralization and participation in integrated coastal management: Policy lessons from Brazil and Indonesia. Ocean \& Coastal Management, 66, 63-72. https://doi.org/10.1016/j.ocecoaman.2012.05.001

Yuliasamaya., Darmawan, A., \& Hilmanto, R. (2014). Perubahan Tutupan Hutan Mangrove Di Pesisir Kabupaten Lampung Timur. Jurnal Sylva Lestari, 2(3), 111. https://doi.org/10.23960/jsl32111-124 